Przegląd Prawa Konstytucyjnego

-ISSN 2082-1212--------

DOI 10.15804/ppk.2017.04.12

$-\mathrm{Nr} 4(38) / 2017$

\title{
Recenzja
}

\section{Jan Wawrzyniak, Sejm a Prezydent Rzeczypospolitej Polskiej i Rada Ministrów, ISBN 978-83-7666-461-3, Wydawnictwo Sejmowe, Warszawa 2016, ss. 176}

Patrząc na różne definicje „państwa” można uznać, że ma ono wiele znaczeń i przez każdego z autorów jest inaczej pojmowane ${ }^{1}$. Książka Profesora Jana Wawrzyniaka zatytułowana Sejm a Prezydent Rzeczypospolitej Polskiej i Rada Ministrów, która ukazała się nakładem Wydawnictwa Sejmowego przybliża czym jest państwo i jaka zachodzi relacja między władzą ustawodawczą a wykonawczą. W tej istotnej sprawie nie ma wyraźnej wypowiedzi Autora, jednakże pomocna w tym względzie jest konfrontacja różnych definicji państwa oraz katalog głównych właściwości tej najpowszechniejszej i najistotniejszej formy politycznego zorganizowania państwa. Definiowanie opiera się na tym, iż każdy Autor może posiadać odmienne zdanie na temat jednoznacznej definicji państwa, która stanowi pod wieloma względami najbardziej uniwersalną formę organizacji państwa. Trafne jest spostrzeżenie Autora, który opisał związki między Sejmem a Prezydentem i Radą Ministrów (s. 9, s. 19). O ile związek instytucji Prezydenta i Rady Ministrów jest oczywisty, jako stanowiący oba człony egzekutywy, o tyle relacja i pozycja Sejmu

1 Zob. D. Dudek, Prezydent a rzad - rozdział kompetencji i zadań ustrojowych, [w:] Dwadzieścia lat transformacji ustrojowej w Polsce: 51 Ogólnopolski Zjazd Katedr i Zakładów Prawa Konstytucyjnego, Warszawa, 19-21 czerwca 2009 r. red. M. Zubik, Warszawa 2009, s. 263 i n. 
nastręcza już materiału do dyskusji. Po pierwsze, może chodzić o fakt natury historycznej, po drugie zaś o rodzaj uzasadnienia. Trafne jest spostrzeżenie Autora który zdaje sobie sprawę z tego, że naiwnie byłoby pytać o wzorzec konstytucyjności, jego rekonstrukcję, czy kwestie te na nowo normować (s. 29). Jak wskazuje E. Łętowska odpowiedzi na te pytania, zawarte w każdej kulturze prawnej, przybierają różne formy i według autorki „państwo prawa jest stanem, i to stopniowalnym"2.

Należy podkreślić, iż Autor zwraca uwagę na fakt, iż w czasach współczesnych najpopularniejszą teorią podziału władzy jest analiza Monteskiuszowska (s. 14). W kulturach zachodu teoria podziału władz równorzędnych opiera się na katalogu władz z założenia pozostającymi na tym samym poziomie ${ }^{3}$. Nic też dziwnego, że można postawić pytanie, dotyczące istoty tej władzy ${ }^{4}$. Bogactwo problemów prawnych Autor skupił na Sejmie i Prezydencie oraz Radzie Ministrów opierając swoje spostrzeżenia na podziale władzy ustawodawczej i władzy wykonawczej, nieznacznie mówi tylko o władzy sądowniczej (s. 16, s. 32), gdyż ten obszar badawczy nie mieścił się w recenzowanym tomie ${ }^{5}$. Z obecnego punktu widzenia władzę wykonawczą w Polsce sprawuje Prezydent i Rada Ministrów, ustawodawczą: Sejm i Senat. Jak wskazują inni autorzy „niezależnie od wielu sporów i kontrowersji na temat wyboru $<<$ modelu $>$ ustrojowego władzy jako fundamentu organizacyjno - ustrojowej struktury władzy państwowej istniała powszechna zgodność poglądów głównych sił politycznych"6. Są to długotrwałe, dojrzałe, żywe, utrwalone i wpływowe tradycje prawne a każda $\mathrm{z}$ wymienionych władz samodzielnie wykonuje

2 E. Łętowska, Trudności w przyswajaniu w Polsce praktyki państwa prawa, [w:] Zasady demokratycznego państwa prawa w konstytucji, red. S. Wronkowska, Warszawa 2006, s. 198.

3 A. Sylwestrzak, Władza neutralna w świetle nowej interpretacji podziału władz, [w:] Konstytucje prawa konstytucyjnego $w$ dobie integracji europejskiej. Ksiega jubileuszowa dedykowana Prof. Marii Kruk-Jarosz, red. J. Wawrzyniak, M. Laskowska, Warszawa 2009, s. 116.

4 Monteskiusz, O duchu praw, Kraków 2003, przeł. T. Boy-Żeleński, s. 26.

5 W nauce prawa konstytucyjnego przeważa pogląd, nawiązujący do klasycznej doktryny niemieckiej, że,,podział władzy" stanowi niezbędny konstytucyjny element państwa prawnego. Tak. J. Jaskiernia, Zasady demokratycznego państwa prawnego w sejmowym postępowaniu ustawodawczym, Warszawa 1999, s. 74.

6 R. Mojak, Parlament a rzad w ustroju trzeciej Rzeczypospolitej Polskiej, Lublin 2007, s. 113 i n. 
swoje funkcje o zdolności do zbudowania odpowiedniej większości i dobrej realizacji z władzą wykonawczą. Jak wskazuje L. Garlicki, „w tle dynamiki wzajemnych oddziaływań egzekutywy i legislatywy (a trzeba raz jeszcze przypomnieć, że w tradycji polskiej równowaga władz zakłada przyznanie parlamentowi nieco silniejszej pozycji) zaznacza się rola władzy sądowniczej ${ }^{7}$. Należy przypomnieć, iż do katalogu najważniejszych zasad należy mechanizm racjonalizacji działania władz. Przestrzeganie wspomnianych norm prawnych sprowadza się do tego, że poza tym żadna z tych władz nie ma charakteru pomocniczego czy kontrolnego nad pozostałymi władzami. Z obecnego punkty widzenia wszystkie muszą działać względem siebie komplementarnie. Źródła owych wzorców tkwią w zasadzie współdziałania władz dla dobra państwa i obywateli. W obrębie wspomnianego podziału władzy ma ona rzecz jasna sens historyczny, tworzy on zasadę ustroju demokratycznego wyrastającego z liberalizmu politycznego, jako ideologii oświecenia. Dla potrzeb rozważań należy tylko przypomnieć, że umieszczając Prezydenta Rzeczypospolitej i Radę Ministrów w systemie władzy wykonawczej, konstytucyjny ustawodawca zapewnił im szczególną pozycję. Należy zaznaczyć nie wchodząc w ściślejszą analizę woli ani rozważań nad jej legitymacją do zarządzania i kierowania, musimy stwierdzić, że tak kierująca wola jest cechą nieodłączną każdej z tych władz, trzeba ją więc czymś wyróżnić, aby mogła stać się wyłącznie właściwością państwa.

Zacytowani powyżej znawcy doktryny uświadamiają nam jak ważny temat poruszył Autor w recenzowanej książce. Po takim zdefiniowaniu nadal pozostaje aktualne pytanie ,jak się ma łączenie funkcji w legislatywie i egzekutywie do zasady podziału władz?"» Niepołączalność tych funkcji historycznie stanowiła jedną z kamieni węgielnych, na których budowana była ta zasada.

Tytuł książki Jana Wawrzyniaka zakłada moim zdaniem, dokonanie analizy wszystkich podstawowych ról pełnionych przez te organy, wynikających z Konstytucji oraz jej rozwinięcia ustawowego, a ponadto ukazuje ich rolę

7 L. Garlicki, System rzadów III RP - dawne obawy a nowe wyzwania, [w:] XL lat obowiązywania Konstytucji z 1997 r. Księga jubileuszowa dedykowana Zdzisławowi Jaroszowi, red. M. Zubik, Warszawa 2012, s. 114.

8 J. Ciemniewski, Podział władz w „Małej Konstytucji” (Kilka uwag o stosunkach miedzy parlamentem i rzadem), [w:] „Mała konstytucja” w procesie przemian ustrojowych w Polsce, red. M. Kruk, Warszawa 1993, s. 31 i n. 
w politycznym układzie sił. Kryterium przyjęte przez Autor jest jak najbardziej uprawnione w celu zachowania praktycznego stopnia rozważań.

Autor recenzowanej książki współtworzy kompleks zagadnień o charakterze opisowym. Należy do nich opisanie pojęć, statusu i przejawów działań tych podmiotów. Z tych wywodów jednak, mających przede wszystkim charakter empiryczny, poszukując systematyzacji spostrzeżeń i faktów i uniknięcia powstających trudności teoretycznych, nie wynika ani jak władza powstać może, ani dlaczego i skąd może mieć tę wyższość, ani w czym się wyraża jej wszechogarniająca skuteczność. Doświadczenia wskazują, że wola władzy musi być jej wolą. Nawet jeśli Autor kierował się głównie względami praktycznymi, nawet jeżeli zaciążyły na nim decyzje nie wprowadzania zmian merytorycznych, choć upływ czasu po ich pierwotnym sporządzeniu mógłby stanowić powód by niektóre tezy omawiające całość problemu uzupełnić lub rozszerzyć. Zestawienie tych dwóch władz w niniejszy opracowaniu skłania do wniosku, że władza jest to forma stosunku pomiędzy przeciwstawnymi a uzupełniającymi się nawzajem władzami, czyli opisania mechanizmów rządzących nad tymi władzami.

Niemniej jednak sposób opisania w recenzowanym tomie przedstawia w trzech częściach analizę eksperta o zróżnicowanym charakterze. We wstępie książki Autor podkreśla iż, opracowanie ma na celu przekazanie czytelnikowi możliwie najszerszych informacji na temat samego Sejmu, jednakże w związku z działalnością i rodzącymi się na tej podstawie problemami należałoby poświęcić temu zagadnieniu kilka monografii, co jest oczywiście punktem wyjścia dla analizy dla kolejnych autorów (s. 5). Poszczególne części zostały ujęte tematycznie, w ramach których usytuowano konkretne zagadnienia. Pozycja zawiera w swej treści cytaty z piśmiennictwa, które Autor wplótł w tekst publikacji (s. 15, s. 18, s. 29, s. 52, s. 56).

Dyskusja o znaczeniu władz której Autor poświecił znacząca część pracy nie należy do czysto teoretycznych, akademickich debat ale jak odzwierciedla ona autentyczne dylematy, problemy, konflikty występujące na styku władz. O ile przyjmujemy, że władza jest formą stosunków pomiędzy tymi władzami skłania do postawienia wniosku, że pomiędzy tymi władzami zachodzi inicjatywa kierownicza z aprobowaną władzą wykonawczą, pomiędzy jakimś nakazem ze strony narodu, a z drugiej strony obowiązkiem. Każda władza jest zależna od innej władzy, a pomiędzy nimi istnieje związek. Nie można jednak 
problemu sprowadzać do prostej alternatywny. Skomplikowana rzeczywistość w tematach podjętych przez Autora sprowadza się do węzłowych zagadnień poświęconych funkcji ustrojodawczej parlamentu w kontekście kompetencji Prezydenta RP, funkcji ustawodawczej Sejmu w kontekście Rady Ministrów, realizacji funkcji kontrolnej Sejmu w stosunku do Rady Ministrów oraz funkcji kreacyjnej Sejmu w kontekście relacji Sejm - Rada Ministrów (s. 50, s. 73 i s. 83). Książka w syntetyczny sposób ujmuje problemy w niej opisane, które mogą stanowić bazę dydaktyczną. W tym miejscu możemy tylko dopowiedzieć, że teoria pochodzenia władzy została opisana w sposób demokratyczny (s. 9). Rzecz bowiem w tym, że teorie demokratyczne znajdują swój wyraz w tezach umowy społecznej Rousseau i jego nauce o woli społecznej o czym pisze Autor. O prezydencie zwykło się mówić że pełni on rolę arbitra (s. 77).

I w tym właśnie czynniku dostrzegamy jak wskazuje M. Kruk „polski system konstytucyjny w odniesieniu do relacji legislatywa - egzekutywa w zasadzie przewiduje procedury zaradcze, choć nie zawsze musi to oznaczać ich uruchomienie. Nie można zapominać jednak, iż system instytucji prawnych nie funkcjonuje w próżni: jest poddany stałej kontroli opinii publicznej i działań wszystkich contre - pouvoires stanowiących w sumie i w ogólnym rachunku potężny korektor władzy"9. W globalnych rozważaniach granice wyboru, określone przez normatywny ład przedmiotowy odnosiły się bardziej do uzasadnienia istnienia władzy i treści stanowionego przez nie prawa niż do rodzaju perforowanego ustroju.

W Książce tekst zamieszczony w omawianej publikacji został opatrzony podtytułami umieszczonymi na marginesach co ułatwia czytelnikowi odnajdywanie tematów, które leżą w jego kręgu zainteresowań. Na wstępie Autor przedstawia problem, który następnie omawia przedstawiając stosowne wnioski. Autor odwołuje się także do dokumentów i materiałów źródłowych w postaci ustaw i tabeli (s. 59). Cenne w tym zabiegu jest to, że materiał źródłowy stanowi wartościowy przedmiot badawczy. Inną próbę rozwinięcia zagadnienia władzy Autor przedstawia w części III w rozdziale III. Jednakże Autor zastrzega, że nie jest to siła nieograniczona, ale przeciwnie, jest ona poddana prawu obiektywnemu. To poddanie siły państwowej prawu konsty-

9 M. Kruk, Konstytucyjny system rządów. Założenia i praktyka, [w:] 25 lat transformacji ustrojowej $w$ Polsce i w Europie Środkowo-Wschodniej, red. E. Gdulewicz, W. Orłowski, S. Patyra, Lublin 2015, s. 27. 
tucyjnemu wynika z całokształtu teorii państwa o której ze znajomością tematu pisze Autor.

Teza przewodnia książki oczywiście nie wyczerpuje całej problematyki ujętej w Konstytucji RP czy regulaminach, jednakże stanowi i rozwiązuje problemy dnia codziennego, które niejako stały się podstawą do powstania niniejszej publikacji. Wybór i podział tematów na części nie był więc czysto przypadkowy. Strefy te znajdują się w zakresie tym bardziej wnikliwego zainteresowania i uzasadnionych ocen, im bardziej i częściej opisywane są relacje egzekutywy i legislatywy. To połączenie tematów sprawia, że mamy dosłowny opis władzy jej istoty zakresu działania co w konsekwencji oznacza, że każda z władz jest wyłączna i decydująca o sobie, że wszelkie inne przejawy w kwestii podejmowania decyzji muszą być brane pod uwagę.

Książka składa się z rozdziałów, które ujęte są w trzy części. Przykładem tego jest postrzeganie funkcji kreacyjnej Sejmu jako problemu prawnego. $\mathrm{W}$ tych przypadkach chodzi o zagadnienie głębokości ingerencji w funkcję kreacyjną postrzeganą z różnych punktów widzenia, a dokładnie rzecz ujmując o zakres postępowania. W następstwie tych rozważań możemy mówić, iż problematyka ta nie jest prezentowana po raz pierwszy. Obydwie kategorie tych procesów są jednakowo pierwotne i jednakowo silne. Siła tych dwóch władz jest tak wielka i trwała, że na nich opiera się niemalże cały system. Tak więc z jednej strony Autor opisuje władzę ustawodawczą z drugiej strony uzależnia władzę wykonawczą od wytwarzanych przez tę władzę procesów i od zakresu działania państwa.

Drugą cechą wyróżniającą omawianą publikację, jest to że w przytoczonych częściach Autor najpierw ocenia spostrzeżenia doktrynalne a następnie w części drugiej i trzeciej analizuje już najbardziej teoretyczne ujęcie relacji Sejmu z Prezydentem i Radą Ministrów. Istoty władzy Autor szuka nie tylko w normatywnym ujęciu, ale i w doktrynalnym spostrzeżeniu. W książce Autor opisuje tylko węzłowe problemy tych dwóch władz. Polemizując z wywodami Autora, należy też od razu zaznaczyć, iż relacja między tymi organami wymaga odrębnego dogłębnego i obszernego opracowania, na co zwraca uwagę sam Autor (s. 5). Jednak zawsze sama praktyka parlamentarna wykaże, że należy spojrzeć na te relacje z zupełnie innej płaszczyzny. Właśnie analiza problemu skłania do wniosku, że doktryna pod naporem polityki z pewnością się ugnie. Takie są niestety relacje, gdy do prawa wkracza polityka. 
Na tym tle można postawić pytanie na ile publikacja wpisuje się w nową sytuację prawną. To oczywiście sprawa otwarta nie tylko dla samego Autora. Dla jasności należy tylko dodać, iż Autor w omawianej publikacji odniósł się do wielu artykułów Konstytucji co dla Czytelnika może być pomocne w odkodowywaniu zagadnień przedstawionych i analizowanych przez doktrynę (s. 30 , s. 32 , s. 35 , s. 38 , s. 41 , s. 53 , s. 59 czy s. 61 ).

Kilka uwag Autor poświecił komisjom i realizacji funkcji kontrolnej przez komisje sejmowe. Jak ujmuje Autor Konstytucja w art. 110 ust. 3 rozróżnia komisje stałe i nadzwyczajne. Konstytucyjne odesłanie do regulacji ustawowej jest wyjątkiem od zasady autonomii regulaminowej parlamentu, podyktowane specyfiką prac parlamentarnych działających często w relacjach z podmiotami, których prawa i obowiązki mogą być regulowane jedynie w drodze ustawy. Przepisy zawartego w art. 112 Konstytucji, stanowiącego podstawę autonomii regulaminu Sejmu (s. 61, s. 136). Autor zwraca uwagę na wyjątek, jakim jest komisja śledcza (s. 141-143). Należy tylko przypomnieć, że parlament powołując komisje śledcze nie powinien przekraczać konstytucyjnych i ustawowych granic realizacji funkcji kontrolnej. W tym duchu powinna być kształtowana treść uchwały Sejmu, o której stanowi art. 2 ust. 3 ustawy o komisji śledczej. Powołanie i funkcjonowanie komisji śledczych w praktyce parlamentarnej nasuwa kilka refleksji związanych z tą tematyką o której Autor nie wspomina.

Na uwagę zasługuje fakt, iż w omawianej publikacji Autor w sposób bardzo przystępny opisuje prawo inicjatywy ustawodawczej (s. 52-56, s. 99). Autor wskazuje, iż Konstytucja przyjmując dualistyczny model władzy wykonawczej ${ }^{10}$, przyznaje jednocześnie obu jej organom prawo inicjatywy ustawodawczej. Należy tylko wspomnieć, że dualizm władzy wykonawczej deklarowały również Konstytucje: Marcowa z 1921 r. (art. 2) i Mała Konstytucja z 1992 r. (art. 1) ${ }^{11}$. Autor wskazał, że władza wykonawcza składa się z dwóch organów głowy państwa Prezydenta (organu jednoosobowego) i rządu (organu kolegialnego) (s. 9, s. 35). Wzajemna relacja pomiędzy nimi nie stanowi realizacji żadnego $\mathrm{z}$ modeli ukształtowanych w państwach demokratycznych na co nie do końca jest miejsce by analizować w niniejszej publikacji.

10 Zob. B. Banaszak, Egzekutywa w Polsce - stan obecny i uwagi de lege fundamentali ferenda, „Przegląd Sejmowy” 2006, nr 3, s. 9 i n.

11 Zob. J. Ciemniewski, Podział władz w „Małej Konstytucji”..., s. 23. 
Udział Prezydenta w ustawodawstwie obejmuje prawo inicjatyw ustawodawczej, podpisanie ustawy, prawo weta, ogłoszenie ustawy, uprzednią kontrolę ustaw. Należy dodać, że Autor wskazuje, iż Konstytucja z 1997 r. przyznaje Prezydentowi (oprócz rządu) prawo inicjatywy ustawodawczej, co jest rozwiązaniem niezwykle rzadkim w państwach demokratycznych. Autor zwraca uwagę, że Konstytucja powierza Prezydentowi aktywną rolę w systemie władz, czyniąc go nie tylko biernym przedstawicielem państwa, ale także arbitrem politycznym, gwarantem ciągłości władzy, a w okresach, kiedy większość parlamentarna i rząd reprezentująca inną opcje polityczną nie $\mathrm{z}$ tą, z której się wywodzi, jego uprawnienia mogą stanowić pewną przeciwwagę dla rządowej większości, wpisującą się w Konstytucyjną równowagę władz. $\mathrm{Na}$ tym tle rodzą się pytania czy pierwszym elementem tej gry jest kwestia inicjatywy ustawodawczej (s. 58). W jakim stosunku pozostaje prawo inicjatywy ustawodawczej rządu do zasady podziału władz? Czy inicjatywa ustawodawcza stanowi integralny element władzy ustawodawczej czy też należy ją traktować jako niezbędny element umożliwiający egzekutywie dialog z legislatywą na temat sposobu realizacji jej programu, tzn. instrument realizacji władzy wykonawczej?

Jeśli chodzi o podział na części w recenzowanej książce to Autor stał przed nie lada dylematem. Wybór podrozdziałów tematów i dostosowanie doń rozdziałów nie powinien budzić wątpliwości, gdyż tak to dotychczas interpretowała doktryna. Jeśli chodzi o redakcję niniejszego tomu, to nie można mieć co do tego zastrzeżeń. Ogólnie rzecz biorąc, jeśli chodzi o rozpiętość tematyczną części recenzowanej książki to dotyczy ona problematyki konstytucyjnej, regulaminowej oraz legislacyjnej.

Przedstawiając te uwagi podkreślmy, że nie interesowały nas kwestie szczegółowe, o których ze znajomością rzeczy pisał Autor. Biorąc to wszystko pod uwagę należy podkreślić przede wszystkim szczegółowość i wnikliwość poszczególnych części, które prezentują wysoki poziom znajomości problematyki.

Recenzowana książka jest cenną pozycją źródłową, bardzo przydatną w badaniu problematyki działaniu Sejmu w konfrontacji z władzą wykonawczą. Władza ustawodawcza przede wszystkim Sejm w całości pochodzi z wyborów. Parlament jest zobowiązany do tworzenia najwyższych aktów prawnych ustaw - na podstawie których ustala się później inne akty prawne. 
Władza wykonawcza to działalność polegająca na wykonywaniu zadań państwowych mających na celu realizację dobra ogólnego, interesu publicznego. Pojęcie „władza wykonawcza” a Sejm nastręcza wielu problemów prawnych, organizacyjnych i legislacyjnych. Dotyczy to przede wszystkim merytorycznego zakresu ich działalności. Trzeba jednak zwrócić uwagę na to iż, Autor książki w sposób bardzo czytelny opisuje występujące pomiędzy nimi różnice, powodujące, iż nie można do końca obu pojęć ze sobą utożsamiać. Nie ulega wątpliwości, że z najwyższej mocy prawnej Konstytucji płynie zakaz naruszania, podziału i realizacji zadań władzy co stanowi, że oczywiście granica jest bardzo płynna. Jak wskazują niektórzy autorzy „w systemie parlamentarno - gabinetowym owa presja władzy ustawodawczej na władze wykonawczą ma charakter zinsty tucjonalizowany w konstytucyjnym mechanizmie odpowiedzialności politycznej rządu przed parlamentem"12.

Reasumując, zważyć należy, że recenzowana książka jest niewątpliwie niezmiernie przydatna. Książka niniejsza, zatytułowana Sejm a Prezydent Rzeczpospolitej Polskiej i Rada Ministrów łączy w sobie cechy podręcznika i swego rodzaju przewodnika dla praktyków. Odbiorca zarówno ten, który jest dobrze zorientowany w omawianej problematyce, jak również i ten który dopiero przystępuje do analizy problemu otrzymuje wartościową książkę, godną polecenia. Książka jest napisana w sposób przystępny, stanowi ciekowe źródło poznawcze dla osób, które są zainteresowane organizacją wewnętrzną państwa i relacjami zachodzącymi w organach władzy ustawodawczej i wykonawczej. Książkę Jana Wawrzyniaka z pełnym przekonaniem polecam uwadze Czytelników.

Edyta Tkaczyk Wyższa Szkoła Menedżerska w Warszawie

12 J. Ciemniewski, Podział władz w „Małej Konstytucji”..., s. 38. 